\title{
Volta Potential Evolution of Intermetallics in Aluminum Alloy Microstructure Under Thin Aqueous Adlayers: A combined DFT and Experimental Study
}

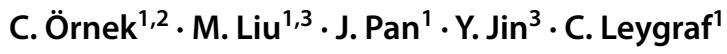

Published online: 13 April 2018

(c) The Author(s) 2018

\begin{abstract}
In this work, first-principle density functional theory (DFT) was used to calculate the work function and Volta potential differences between aluminum alloy matrix and two intermetallic phases $\left(\mathrm{Mg}_{2} \mathrm{Si}\right.$ and $\left.\mathrm{Al}_{2} \mathrm{Cu}\right)$ with varying surface terminations as a function of adhering monolayers (ML) of water. The calculated data were compared with experimental local Volta potential data obtained by the scanning Kelvin probe force microscopy (SKPFM) on a commercial aluminum alloy AA6063-T5 in atmospheric environments with varying relative humidity $(\mathrm{RH})$. The calculations suggest that the surface termination has a major effect on the magnitude and polarity of the Volta potential of both intermetallic phases (IMP's). The Volta potential difference between the IMP's and the aluminum matrix decreases when the surface is gradually covered by water molecules, and may further change as a function of adhering ML's of water. This can lead to nobility inversions of the IMP's relative to the aluminum matrix. The measured Volta potential difference between both IMP's and their neighboring matrix is dependent on RH. Natural oxidation in ambient indoor air for 2 months led to a nobility inversion of the IMP's with respect to the aluminum matrix, with the intermetallics showing anodic nature already in dry condition. The anodic nature of $\mathrm{Al}_{2} \mathrm{Cu}$ remained with the introduction of $\mathrm{RH}$, whereas $\mathrm{Mg}_{2} \mathrm{Si}$ became cathodic at high $\mathrm{RH}$, presumably due to de-alloying of $\mathrm{Mg}$ and oxide dissolution. The DFT calculations predicted an anodic character of both IMP's in reference to the oxidized aluminum matrix, being in good agreement with the SKPFM data. The DFT and SKPFM data were discussed in light of understanding localized corrosion of aluminum alloys under conditions akin to atmospheric exposure.
\end{abstract}

Keywords DFT $\cdot$ SKPFM $\cdot$ Aluminum $\cdot$ Intermetallics $\cdot$ Volta potential $\cdot$ Aqueous adlayer

\section{Introduction}

The interaction of water with any solid surface under ambient pressure conditions is a topic of profound scientific and technical importance. The literature includes experimental and theoretical studies in diverse research areas such as

\section{Leygraf}

chrisl@kth.se

1 Division of Surface and Corrosion Science, Department of Chemistry, KTH Royal Institute of Technology, Drottning Kristinas Väg 51, 10044 Stockholm, Sweden

2 Department of Corrosion in Energy and Process Industry, Swerea KIMAB AB, Isafjordsgatan 28A, 16440 Kista, Sweden

3 National Center for Materials Service Safety, University of Science and Technology of Beijing, Xueyuan Road 30, 100083 Beijing, China heterogeneous catalysis (Refs. [1,2] are examples of recent publications), meteorology [3, 4], geology [5, 6], physical chemistry [7, 8], solar energy conversion [9-11], pharmacy [12], atmospheric chemistry [13], electrochemistry [14, 15], tribology [16, 17], and corrosion science [18, 19]. Advancements in experimental and computational techniques have resulted in considerable progress in our fundamental view of water-solid interactions, and the research field has been summarized in a few most comprehensive reviews [20-22].

In atmospheric corrosion, which is the most common and perhaps most complex form of corrosion, the presence of an ultra-thin ubiquitous aqueous adlayer is of fundamental importance [23, 24]. Atmospheric corrosion involves three phases (atmosphere, liquid, and solid) and two interfaces (atmospherelliquid, liquidlsolid), whereby the aqueous film (often referred to as aqueous adlayer) interacts with the atmosphere and the solid (metal) through a variety of simultaneously acting physicochemical processes [23]. Detailed 
experimental analysis has shown that most solid surfaces are moist when in contact with ambient air [23]. The amount of adhering water (coverage) depends on different surfacerelated properties, such as porosity, microstructure, surface hydroxylation, degree of oxidation, and the presence of hygroscopic species [23]. On a clean metal surface, the amount of water present at room temperature increases from a few equivalent ML's of water at $40 \%$ RH to approximately ten ML's at $90 \%$ RH [25].

Through instrumental developments and better access of techniques, such as the quartz crystal microbalance (QCM) [26, 27], surface vibrational spectroscopy [28-30], and local probing techniques [31,32], our molecular understanding of the role of the aqueous adlayer in atmospheric corrosion has greatly improved. A technique of special interest in this context is the SKPFM which can provide information about the Volta potential of a locally-probed metallic area in nanometer resolution while the surface is typically in contact with the ambient air [33]. The Volta potential can provide meaningful information about the relative electrochemical nobility of microstructural phases during initial aqueous corrosion of metals or alloys [34, 35], yet without a clear understanding of the theory behind.

An important step was recently taken when first principle calculations were performed on IMP's in an aluminum alloy, whereby the computational results of Volta potential differences between the IMP's and the surrounding aluminum matrix showed good agreement with experimental data obtained by SKPFM [36]. In the current study these efforts have advanced one step further by comparing theoreticallydeduced Volta potential differences calculated by DFT with local Volta potential differences measured on a commercial aluminum alloy (AA6063-T5) by SKPFM. DFT has been used to obtain Volta potential differences between two IMP's ( $\mathrm{Mg}_{2} \mathrm{Si}$ and $\mathrm{Al}_{2} \mathrm{Cu}$ with different surface atomic terminals) and the aluminum matrix in the presence of up to two ML's of water. SKPFM was performed in the presence of wellcontrolled humidified air on a commercial aluminum alloy
(AA6063-T5) to measure the difference in Volta potentials between the same IMP's and the surrounding aluminum matrix at different RH. Finally, the computational and experimental data have been compared and discussed in light of understanding localized corrosion of complex aluminum alloys under conditions akin to atmospheric exposure.

\section{DFT Calculations}

The work function of bare aluminum (Al), one stable phase of $\mathrm{Al}$ oxide, $\alpha-\mathrm{Al}_{2} \mathrm{O}_{3}$, and two IMP's, namely $\mathrm{Mg}_{2} \mathrm{Si}$ and $\mathrm{Al}_{2} \mathrm{Cu}$, as a function of adhering $\mathrm{ML}$ of $\mathrm{H}_{2} \mathrm{O}$ were calculated. Then, from these data their corresponding Volta potentials, the Volta potential differences between the IMP's and the $\mathrm{Al}$ matrix, and the Volta potential changes upon surface coverage of adhering $\mathrm{H}_{2} \mathrm{O}$ were calculated. This allowed direct comparison of DFT calculations with Volta potentials measured by SKPFM.

Figure 1 displays the atomic structures of the calculated slabs for $\mathrm{Al}(111), \alpha-\mathrm{Al}_{2} \mathrm{O}_{3}(0001), \mathrm{Mg}_{2} \mathrm{Si}(111)$ with $\mathrm{Mg}$ - and Si-terminals, $\mathrm{Mg}_{2} \mathrm{Si}(110)$ with $\mathrm{MgSi}$-terminal, and $\mathrm{Al}_{2} \mathrm{Cu}(110)$ with $\mathrm{Al} 2$ - (two outermost layers of $\mathrm{Al}$ ) and $\mathrm{Cu}$-terminals, which are constructed in a $2 \times 2$ surface area showing several atomic layers. In this way, $\mathrm{H}_{2} \mathrm{O}$ molecules could be introduced onto the surface and the interactions between $\mathrm{H}_{2} \mathrm{O}$ molecules and the substrate as well as among the $\mathrm{H}_{2} \mathrm{O}$ molecules were taken into account in all calculations. The calculation slabs were chosen thick enough to approximate their bulk properties. Each surface of the slabs was separated by a large enough vacuum gap, keeping the interaction of the surfaces with other systems at zero. Then, to study the effect of humidity, the work functions of the systems with and without water adsorption were calculated with several possible configurations of $\mathrm{H}_{2} \mathrm{O}$ molecules at water coverages $(\theta)$ at $0.25,0.5,1$, and $2 \mathrm{ML}$ of $\mathrm{H}_{2} \mathrm{O}$. One $\mathrm{ML}$ of
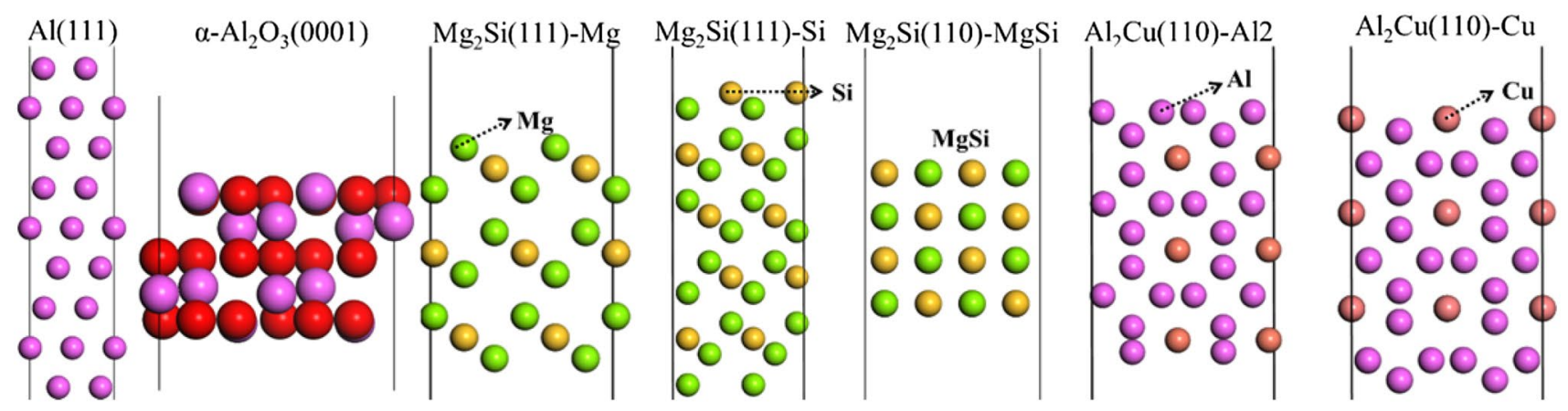

Fig. 1 Atomic structures (slab) of $\mathrm{Al}(111), \alpha-\mathrm{Al}_{2} \mathrm{O}_{3}(0001), \mathrm{Mg}_{2} \mathrm{Si}$ and $\mathrm{Al}_{2} \mathrm{Cu}$ with different surface terminals used in DFT calculations. Color of the atoms: $\mathrm{Al}$ in purple, $\mathrm{O}$ in red, $\mathrm{Mg}$ in green, $\mathrm{Si}$ in yellow, and $\mathrm{Cu}$ in orange 
$\mathrm{H}_{2} \mathrm{O}$ refers to the ratio of the amount of water molecules per surface atom [37].

The DFT calculations were performed using the Dmol3 code based on the GGA-PW91 exchange-correlation energy functional [38]. DFT semi-core pseudopotentials (DSPP) were employed as the core electron treatment with double numeric basis sets and polarization functions (DNP). Brillouin-zone integrations were performed using a $6 \times 6 \times 1 \mathrm{k}$-point mesh size for all surfaces, except for the $\mathrm{Al}$ matrix for which a $3 \times 3 \times 1 \mathrm{k}$-point mesh size was used. A Meshfessel-Paxton smearing of 0.005 Hatree (Ha, $1 \mathrm{Ha}=27.2114 \mathrm{eV}$ ) was used, and dipole corrections were introduced to all surfaces. All surface configurations including those with adhering water molecules were optimized until the energy, residual force, and atomic displacement became less than $10^{-5} \mathrm{Ha}, 0.002 \mathrm{Ha} / \AA$ ( $\mathrm{n}$ gstrom), and $0.005 \AA$, respectively.

Figure 2 shows an optimized atomic configuration of 1 $\mathrm{ML}$ of $\mathrm{H}_{2} \mathrm{O}$ adhering on the surface of $\mathrm{Mg}_{2} \mathrm{Si}(111)$ with $\mathrm{Mg}$ terminal as an example. There are four surface $\mathrm{Mg}$ atoms at the terminal with four adhering $\mathrm{H}_{2} \mathrm{O}$ molecules corresponding to $1 \mathrm{ML}$ of $\mathrm{H}_{2} \mathrm{O}$. The most stable configuration of all structures, having the lowest total energy, was chosen to obtain the work function of the water-covered surfaces.

The work function was calculated according to following equation [39]:

$\phi_{M}=E_{\text {vacuum }}-E_{\text {Fermi }}$

where $\phi_{M}$ is the work function of the metal, $E_{\text {vacuum }}$ is the vacuum energy, and $E_{F e r m i}$ is the Fermi level. The work functions of all bare surfaces have been calculated and reported in previous publication [36], which are in reasonable agreement with other calculations [40, 41]. The reader is referred to these works for detailed explanation of the DFT procedure.

The slab thickness for $\mathrm{Mg}_{2} \mathrm{Si}(111)-\mathrm{Mg}$ and $\mathrm{Mg}_{2} \mathrm{Si}(110)-\mathrm{MgSi}$ was kept to a minimum to limit the required calculating capacity for the water-covered systems. The work function was used to calculate the Volta potential according to following equation:

$\psi_{M}=\frac{\phi_{M}}{e}$

where $\psi_{M}$ is the Volta potential of the metal and $e$ the unit charge of an electron. The understanding of the Volta potential is in accordance to the concept described by Moore and Hummel which, in essence, goes back to the definitions of Erich Lange [42].

For comparison with experimental measurement by SKPFM, the Volta potential difference between the IMP and the atomic force microscopy (AFM) probe $\left(\psi_{I M P}-\psi_{\text {Probe }}\right)$ or the difference between the matrix and the probe $\left(\psi_{\text {Matrix }}-\psi_{\text {Probe }}\right)$ was derived from calculated work function data according to Eqs. (3) and (4). More detailed description about the procedure for calculating Volta potentials of the metal with varying crystallographic orientations of different IMP's can be read elsewhere [36].

$\Delta \psi_{\text {Probe }}^{I M P}=\psi_{I M P}-\psi_{\text {Probe }}=\frac{\phi_{I M P}-\phi_{\text {Probe }}}{e}$

$\Delta \psi_{\text {Probe }}^{\text {Matrix }}=\psi_{\text {Matrix }}-\psi_{\text {Probe }}=\frac{\phi_{\text {Matrix }}-\phi_{\text {Probe }}}{e}$

Focus was given to the change in Volta potential differences between the IMP's and the matrix and, therefore, the effect of the probe was omitted by subtracting Eq. (4) from (a) Side view

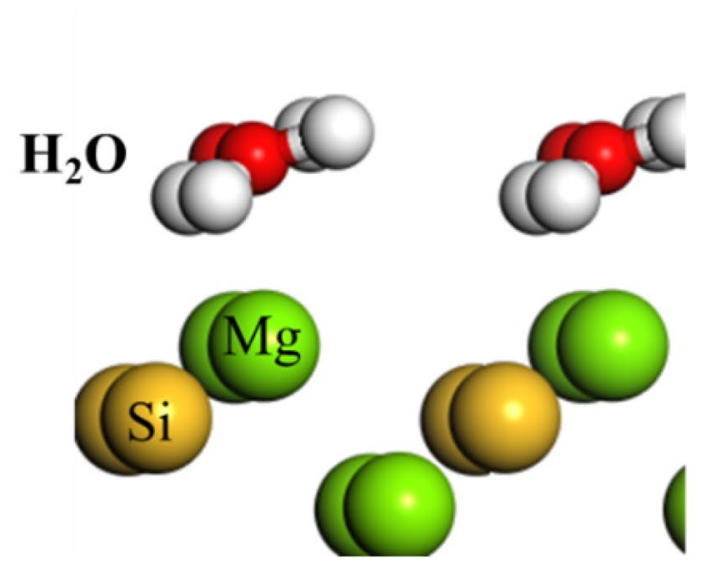

(b) Top view
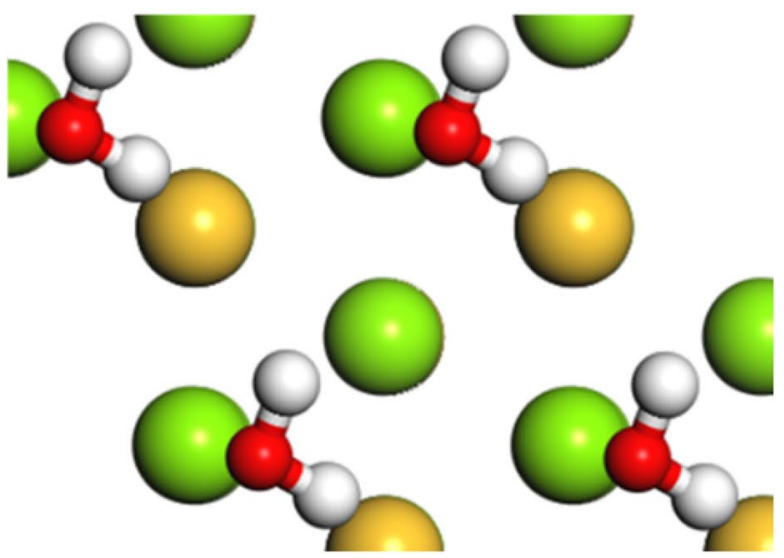

Fig. 2 Optimized atomic configuration of $1 \mathrm{ML}$ of $\mathrm{H}_{2} \mathrm{O}$ adhering on the surface of $\mathrm{Mg}_{2} \mathrm{Si}(111)-\mathrm{Mg}$ terminal: a side view, b top view. O atoms are shown in red, $\mathrm{H}$ in white, $\mathrm{Mg}$ in green, and $\mathrm{Si}$ in yellow colors 
Eq. (3). Then, the Volta potential difference between an IMP and the Al matrix at varying magnitude of water coverage $\theta$ was calculated according to following equation:

$\Delta \psi_{\text {Matrix }}^{I M P}(\theta)=\left(\phi_{\text {IMP }}(\theta)-\phi_{\text {matrix }}(\theta)\right) / e$

where $\phi_{I M P}(\theta)$ and $\phi_{\text {matrix }}(\theta)$ are the work function of the IMP and the Al matrix at a certain magnitude of water coverage $\theta$, respectively. Selected representative terminals were included into the calculation to highlight the importance of surface terminals of the IMP. Only $\mathrm{Al}(111)$ orientation was chosen to represent the Al matrix to simplify the calculation. Moreover, for comparison with aged $\mathrm{Al}$ alloy samples (natural oxidation), $\alpha-\mathrm{Al}_{2} \mathrm{O}_{3}(0001)$ was also chosen to represent an oxide-covered surface of the alloy matrix.

\section{Experimental}

The effect of RH on Volta potential changes of the Al-matrix as well as the IMP's was studied. Discussion is restricted to the IMP's $\left(\mathrm{Mg}_{2} \mathrm{Si}\right.$ and $\left.\mathrm{Al}_{2} \mathrm{Cu}\right)$ as well as their Volta potential differences with respect to the alloy matrix in order to compare with DFT data. The influence of water adsorption on the AFM probe was disregarded. The focus was on the Volta potential difference between the IMP and the matrix and, therefore, the role of the probe was omitted.

\subsection{Material Used}

The extruded, commercial aluminum alloy AA6063-T5 was used in this work. The chemical composition (wt\%) was $0.6 \% \mathrm{Mg}, 0.45 \% \mathrm{Si}, 0.5 \% \mathrm{Fe}, 0.2 \% \mathrm{Zn}, 0.15 \% \mathrm{Ti}, 0.1 \% \mathrm{Cu}$, $0.1 \% \mathrm{Mn},<1.5 \%$ others, and $\mathrm{Al}$ (bal.). Coupon specimens in dimensions of $10 \mathrm{~mm} \times 10 \mathrm{~mm} \times 2.5 \mathrm{~mm}$ were cut from the extruded bar and ground and polished to $1 / 4 \mu \mathrm{m}$ using diamond suspension, followed by an end-polishing using a suspension containing active oxide silica particles (OPS) from Struers (Denmark) for $30 \mathrm{~min}(\mathrm{pH} \mathrm{9)}$. The latter removes gently surface strains originating from the grinding and polishing treatment from the surface and yields smooth surfaces. The sample was stored in ambient air for 2 months for natural oxide growth (aging) to achieve steady-state conditions. Two indents were placed on the surface as fiducial markers using a scriber to easily locate the region of interest for correlative analyses.

\subsection{Microstructure Characterization}

The microstructure of the sample was characterized to identify IMP's and other microstructural details for correlative Volta potential measurements. For this, the JEOL $J S M-7001 F$ scanning electron microscope (SEM) equipped with an Xmax energy-dispersive X-ray (EDX) silicon drift detector (SDD) with $80 \mathrm{~mm}^{2}$ window size from Oxford Instruments was used. EDX was used for chemical analysis to determine phase identification. Information obtained from EDX measurements were interpreted in conjunction with existing X-ray diffraction (XRD) data and geometrical information about the IMP's obtained from SEM analysis and literature reports. SEM imaging was performed in backscattered electron (BSE) and secondary electron (SE) modes. An accelerating voltage of $10-15 \mathrm{kV}$ with high probe current was used for imaging the microstructure. High-resolution EDX measurements were acquired using AZtec V3.3 software from Oxford Instruments using an accelerating voltage of $5 \mathrm{kV}$ with high probe current and high detection resolution (process time 5, dead time 50-60\%).

\subsection{Volta Potential Microscopy}

The SKPFM technique was used to determine local Volta potentials of the microstructure. Volta potential measurements were carried out prior to SEM analyses in order to avoid carbon burnt onto the surface. The Dimension Icon atomic force microscope (AFM) from Bruker with OSCMPt R3 platinum-coated $(20 \mathrm{~nm}) \mathrm{n}$-doped silicon probes from Olympus was used in amplitude modulation (AM-KPFM) mode (two-pass technique). The scan rate was between 0.35 and $0.5 \mathrm{~Hz}$. The scan size varied between $60 \mu \mathrm{m} \times 60 \mu \mathrm{m}$ to $10 \mu \mathrm{m} \times 10 \mu \mathrm{m}$, depending on the region of interest to be mapped. Each map contained $128 \times 128$ or $256 \times 256$ pixels, corresponding to a mapping time between 5 and 17 min with spatial resolutions between 50 and $200 \mathrm{~nm}$. A lift height of $50 \mathrm{~nm}$ was used. A nullifying potential (drive routing) of $6000 \mathrm{mV}$ was applied to the sample. No data flattening, smoothing, or inversion was done. An inversion was not needed because the nullifying bias was applied to the sample which is the same if the bias would have been applied to the tip followed by an inversion. The polarity and magnitude of all measured Volta potentials conform to the classical electrochemical concept in which high values are shown as electrochemically noble (cathodic) and lower ones as electrochemically active (anodic). The potential values in the maps are in reference to Pt.

Data interpretation was done according to the following equation in accordance to the description provided by Moore and Hummel [42]:

$\psi_{S}=\psi_{P t}+V_{C P D}$

where $\psi_{S}$ is the local Volta potential of the sample, $\psi_{P t}$ the Volta potential of the AFM probe (here Pt), and $V_{C P D}$ the contact potential difference i.e. the measured local Volta potential difference between the sample and the probe.

Platinum is typically one of the most noble metals and is nobler than aluminum. However, oxide on the surface of aluminum and other metals can enhance the work function 
and consequently increase its Volta potential to nobler values [43]. If the sample is the routing drive (as in this paper), then $\psi_{S}$ is nobler than $\psi_{P t}$ for positive $V_{C P D}$. Conversely, if $V_{C P D}$ is negative, then $\psi_{S}$ is less noble than $\psi_{P t}$ (not applicable to the data reported in this paper, but an important complimentary information to understand the polarity convention of $\left.V_{C P D}\right)$. In this paper, areas on the sample with lower measured $V_{C P D}$ (Volta potential difference) indicate electrochemically-active (anodic) character, whereas higher $V_{C P D}$ imply higher electrochemical nobility (cathodic) with respect to each other. In this context, $V_{C P D}$ and the Volta potential difference between the local microstructural site and the probe are quantitatively the same and will be denoted as "Volta potential vs. Pt" in further communication. It should be noted that all measured potentials with their interpretations have been carefully checked by measuring against a known reference. The PFKPFM-SMPL reference sample from Bruker, which has discrete regions of $\mathrm{Au}$ and $\mathrm{Al}$ coating, was used for this purpose.

The Volta potential indicates the relative tendency of metals to corrosion and can help to assess the severity of localized corrosion in alloys with complex microstructures $[42,44-46]$. In a galvanic couple, the phase with higher electrochemical nobility has typically higher Volta potentials and usually acts as the cathode, whereas that with lower Volta potentials acts as the anode [47, 48]. For a detailed interpretation of the polarity the reader is referred to previous works [47, 49, 52].

All SKPFM measurements were performed in controlled atmospheric environment, with the $\mathrm{RH}$ ranging between 25 and $95 \%$. The sample was mounted in a humidity cell from Bruker and the humidity was provided by a Cellkraft $P-2$ humidifier using a flow rate of $200 \mathrm{nccm}$. The temperature and humidity were continuously recorded by a Sensirion SHTC1/SHTW2 USB sensor connected to a laptop. The cell temperature was kept constant at $23{ }^{\circ} \mathrm{C}$. Volta potential measurements over a region of $60 \mu \mathrm{m} \times 60 \mu \mathrm{m}$ containing an $\mathrm{Al}_{2} \mathrm{Cu}$ IMP were performed at 25, 51, 81, 84, and $88 \% \mathrm{RH}$ with $\pm 3 \%$ uncertainty. At least 30 min were given to equilibrate, and then the Volta potential differences were measured repeatedly to achieve reproducible and reliable data. Then, the relative humidity was increased to the next increment when no further changes were observed. The humidity was set back to ambient humidity ( $27 \% \mathrm{RH})$ to monitor remaining Volta potential changes.

Next, further Volta potential measurements over a region of $8 \mu \mathrm{m} \times 8 \mu \mathrm{m}$ containing an $\mathrm{Mg}_{2} \mathrm{Si}$ IMP was carried out on the same sample at $27,60,90$, and $95 \%$ RH with $\pm 3 \%$ uncertainty. The humidity was also set back to ambient air at the end of the measurement to monitor remaining Volta potential changes. Potential (vs. Pt) and corresponding topography (height) maps were produced using Nanoscope V1.6 from Bruker. The data was not flattened. Potential line profiles were sectioned from selected sites and plotted in potential vs. distance charts, from which the Volta potential difference between the IMP and the alloy matrix was obtained. Interpretation of SKPFM data was done in accordance to previous works [49-52].

\section{Results}

\subsection{DFT Calculations of the Work Function and Volta Potential Differences}

Table 1 summarizes calculated work functions of all bare surfaces without and with $\mathrm{H}_{2} \mathrm{O}$ adlayers (from 0 to $2 \mathrm{ML}$ ). For $\mathrm{Al}(111)$, a coverage of $0.25 \mathrm{ML}$ of $\mathrm{H}_{2} \mathrm{O}$, which corresponds to a single water molecule present on the surface of the calculation slab, leads to an abrupt work function decrease from 4.16 to $3.05 \mathrm{eV}$. Further increase of the water coverage to $1 \mathrm{ML}$ increases the work function to $4.16 \mathrm{eV}$. The work function changes only slightly when the water coverage is further increased to $2 \mathrm{ML}$ of $\mathrm{H}_{2} \mathrm{O} . \alpha-\mathrm{Al}_{2} \mathrm{O}_{3}(0001)$ has a high work function $(6.72 \mathrm{eV})$ when no water adsorbs, and its work function changes slightly $(\sim 0.7 \mathrm{eV}$ at $0.25 \mathrm{ML})$ with the increase of water coverage. The work function of $\mathrm{Al}_{2} \mathrm{Cu}(110)$ shows a small difference between $\mathrm{Cu}$ and $\mathrm{Al}_{2}$ terminals, and a similar trend of obvious drop followed by a rise for both $\mathrm{Cu}$ and $\mathrm{Al} 2$ terminals with increasing $\mathrm{H}_{2} \mathrm{O}$ coverage, i.e. decreasing first but then increasing again, having
Table 1 Calculated work functions $\left(\phi_{M}\right)$ of $\mathrm{Al}$, $\alpha-\mathrm{Al}_{2} \mathrm{O}_{3}(0001), \mathrm{Mg}_{2} \mathrm{Si}$, and $\mathrm{Al}_{2} \mathrm{Cu}$ surfaces with different surface terminal as a function of adhering $\mathrm{H}_{2} \mathrm{O}$ molecules and magnitude of water coverage $\left(\theta_{\mathrm{H}_{2} \mathrm{O}}\right)$

\begin{tabular}{|c|c|c|c|c|c|c|c|}
\hline \multirow{3}{*}{$\begin{array}{l}\mathrm{H}_{2} \mathrm{O} \text { cover- } \\
\text { age (ML) }\end{array}$} & \multicolumn{7}{|c|}{ Work function $(\mathrm{eV})$} \\
\hline & \multirow[t]{2}{*}{$\mathrm{Al}(111)$} & \multirow[t]{2}{*}{$\alpha-\mathrm{Al}_{2} \mathrm{O}_{3}(0001)$} & \multicolumn{3}{|l|}{$\mathrm{Mg}_{2} \mathrm{Si}$} & \multicolumn{2}{|l|}{$\mathrm{Al}_{2} \mathrm{Cu}$} \\
\hline & & & (111)-Mg & (111)-Si & (110)-MgSi & (110)-A12 & $(110)-\mathrm{Cu}$ \\
\hline 0 & 4.16 & 6.72 & 3.29 & 5.39 & 4.19 & 4.33 & 4.52 \\
\hline 0.25 & 3.05 & 6.15 & 3.16 & 4.52 & 2.67 & 3.65 & 4.19 \\
\hline 0.5 & 3.43 & 6.07 & 2.94 & 4.38 & 3.02 & 3.21 & 3.62 \\
\hline 1 & 4.16 & 6.75 & 2.83 & 3.35 & 3.1 & 3.46 & 3.46 \\
\hline 2 & 4.14 & 6.56 & 2.64 & 2.72 & 2.75 & 3.84 & 4.25 \\
\hline
\end{tabular}


the lowest level at $0.5 \mathrm{ML} \mathrm{H}_{2} \mathrm{O}$ for the $\mathrm{Al}_{2}$ terminal and 1 $\mathrm{ML} \mathrm{H}_{2} \mathrm{O}$ for the $\mathrm{Cu}$ terminal, respectively.

In contrast, there is a significant influence of the surface terminal on the work function of $\mathrm{Mg}_{2} \mathrm{Si}$. Without $\mathrm{H}_{2} \mathrm{O}$ on the surface, the work function of $\mathrm{Mg}_{2} \mathrm{Si}-\mathrm{Si}$ and $\mathrm{Mg}_{2} \mathrm{Si}-\mathrm{Mg}$ is 5.4 and $3.3 \mathrm{eV}$, respectively, clearly showing a large difference between both terminals. The work function of both terminals decreases with the increase of $\mathrm{H}_{2} \mathrm{O}$ coverage. $\mathrm{Mg}_{2} \mathrm{Si}$ with $\mathrm{MgSi}$-terminal and $\mathrm{Al}(111)$ have similar work functions when no water is present, but show large differences when the surface is covered by water. The work function of $\mathrm{Mg}_{2} \mathrm{Si}-\mathrm{MgSi}$ decreases dramatically with $0.25 \mathrm{ML}$ of $\mathrm{H}_{2} \mathrm{O}$ adsorption, and shows alternating behavior with further rise of $\mathrm{H}_{2} \mathrm{O}$ coverage. All surface terminals of $\mathrm{Mg}_{2} \mathrm{Si}$ have similar work functions when covered with $2 \mathrm{ML}$ of $\mathrm{H}_{2} \mathrm{O}$ (converging trend).

The calculated Volta potential difference between the IMP $\left(\mathrm{Mg}_{2} \mathrm{Si}\right.$ and $\mathrm{Al}_{2} \mathrm{Cu}$ with different surface terminals) and $\mathrm{Al}(111)$ and $\alpha-\mathrm{Al}_{2} \mathrm{O}_{3}(0001)$ is shown in Fig. 3. Apparently, $\mathrm{Mg}_{2} \mathrm{Si}$ and $\mathrm{Al}_{2} \mathrm{Cu}$ can be either anodic or cathodic relative to $\mathrm{Al}(111)$ (Fig. 3a), depending on the surface terminal and the level of $\mathrm{H}_{2} \mathrm{O}$ coverage. The potential difference between the IMP's for all terminals and $\mathrm{Al}(111)$ decreases gradually with the increase of water coverage from 0.25 to $1 \mathrm{ML}$. $\mathrm{Al}_{2} \mathrm{Cu}(110)$ with both terminals and $\mathrm{Mg}_{2} \mathrm{Si}(111)$ with $\mathrm{Si}$-terminals are cathodic with respect to $\mathrm{Al}(111)$ at 0.25 ML. With the increase in water coverage, their nobilities invert from cathodic to anodic with respect to $\mathrm{Al}(111)$. $\mathrm{Al}_{2} \mathrm{Cu}(110)-\mathrm{Cu}$ becomes slightly cathodic again upon coverage of $2 \mathrm{ML}$. Seemingly, the Volta potential difference becomes negative for both phases with all terminals, indicating anodic character of the IMP's relative to $\mathrm{Al}(111)$ when the surface is fully covered by water ( $\geq 1 \mathrm{ML})$. The Volta potential difference between the IMP's and $\alpha-\mathrm{Al}_{2} \mathrm{O}_{3}(0001)$ are negative, implying that the IMP's have anodic character in reference to the $\alpha-\mathrm{Al}_{2} \mathrm{O}_{3}(0001)$. Their anodic nobility remain for all magnitudes of water coverage (Fig. 3b).

In a nutshell, the DFT calculations suggest that the Volta potential difference between the IMP's $\left(\mathrm{Mg}_{2} \mathrm{Si}\right.$ and $\left.\mathrm{Al}_{2} \mathrm{Cu}\right)$ and $\mathrm{Al}(111)$ decreases when the surface of the IMP is covered by a ML of adhering $\mathrm{H}_{2} \mathrm{O}$. The IMP's are anodic with respect to the Al-matrix at water coverages of 1-2 ML of $\mathrm{H}_{2} \mathrm{O}$, whereas they always show anodic character relative to $\alpha-\mathrm{Al}_{2} \mathrm{O}_{3}(0001)$ at all water coverage calculated here. A striking result is that $\mathrm{Mg}_{2} \mathrm{Si}(111)-\mathrm{Si}$ changes from a strong cathodic to a strong anodic character when the magnitude of $\mathrm{H}_{2} \mathrm{O}$ coverage increases from 0.25 to $2 \mathrm{ML}$. Aged aluminum (oxide) has apparently large Volta potential differences as contrasted to bare aluminum (freshly polished), having also large impact on the relative nobilities among microstructural constituents (IMP's) which may differ from each other.

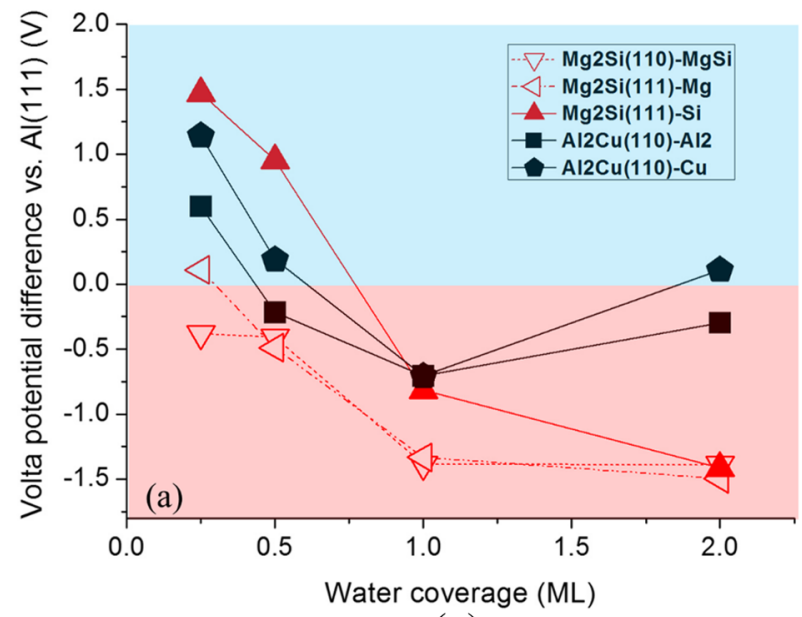

(a)

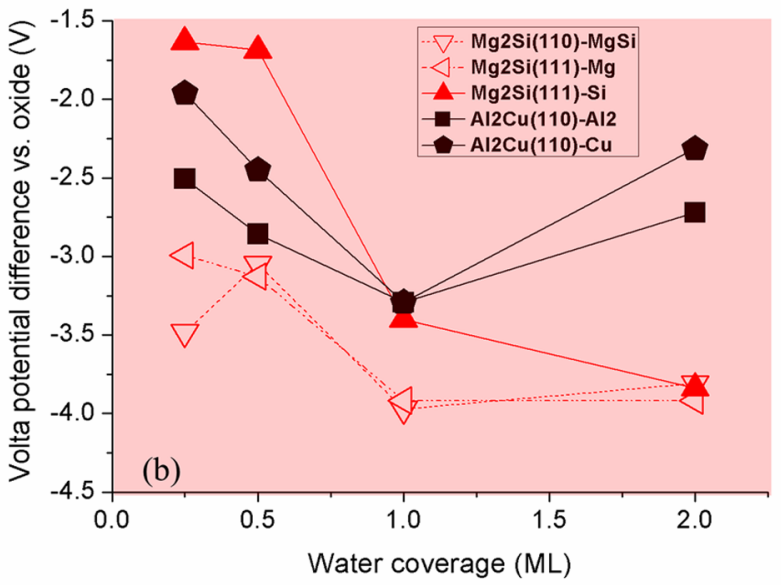

(b)

Fig. 3 Calculated Volta potential difference of IMP's $\left(\mathrm{Mg}_{2} \mathrm{Si}\right.$ and $\mathrm{Al}_{2} \mathrm{Cu}$ with different surface terminals) relative to $\mathrm{Al}(111)$ (a) and $\alpha-\mathrm{Al}_{2} \mathrm{O}_{3}(0001)$ (b) as a function of $\mathrm{H}_{2} \mathrm{O}$ coverage. Negative values imply anodic character (red background) and positive values imply cathodic character (blue background) of the IMP's relative to the matrix

\subsection{Microstructure}

The microstructure of the alloy contains $\mathrm{Al}_{4.01} \mathrm{Mn}(\mathrm{Fe}, \mathrm{Cr}, \mathrm{Ti})$ $\mathrm{Si}_{0.74}, \mathrm{Al}_{1.69} \mathrm{Mg}_{4} \mathrm{Zn}_{2.31}, \mathrm{FeAl}_{3}, \mathrm{Al}_{2} \mathrm{Cu}, \mathrm{ZnAl}_{2}$, and $\mathrm{Mg}_{2} \mathrm{Si}$ IMPs, all IMP's embedded in the extruded matrix, as confirmed by XRD and high-resolution SEM analyses. Feand Cr-rich $\mathrm{Al}_{4.01} \mathrm{MnSi}_{0.74}$ constitutes the majority of all IMP's and they are block-shaped with sizes of 1-10 $\mu \mathrm{m}$. $\mathrm{Al}_{1.69} \mathrm{Mg}_{4} \mathrm{Zn}_{2.31}$ and $\mathrm{FeAl}_{3}$ are also block-shaped and have similar dimensions to $\mathrm{Al}_{4.01} \mathrm{MnSi}_{0.74}$. $\mathrm{Al}_{2} \mathrm{Cu}$ IMP's are spherical with diameters of $50-400 \mathrm{~nm}$. $\mathrm{Mg}_{2} \mathrm{Si}$ also appears spherical with sizes typically $\leq 500 \mathrm{~nm}$. The fraction of $\mathrm{Mg}_{2} \mathrm{Si}$ is low, having a fraction of $\approx 0.1 \mathrm{vol} \%$. In the SEM images, all precipitates show brighter contrast than the matrix except for $\mathrm{Mg}_{2} \mathrm{Si}$, which exhibits a darker contrast 


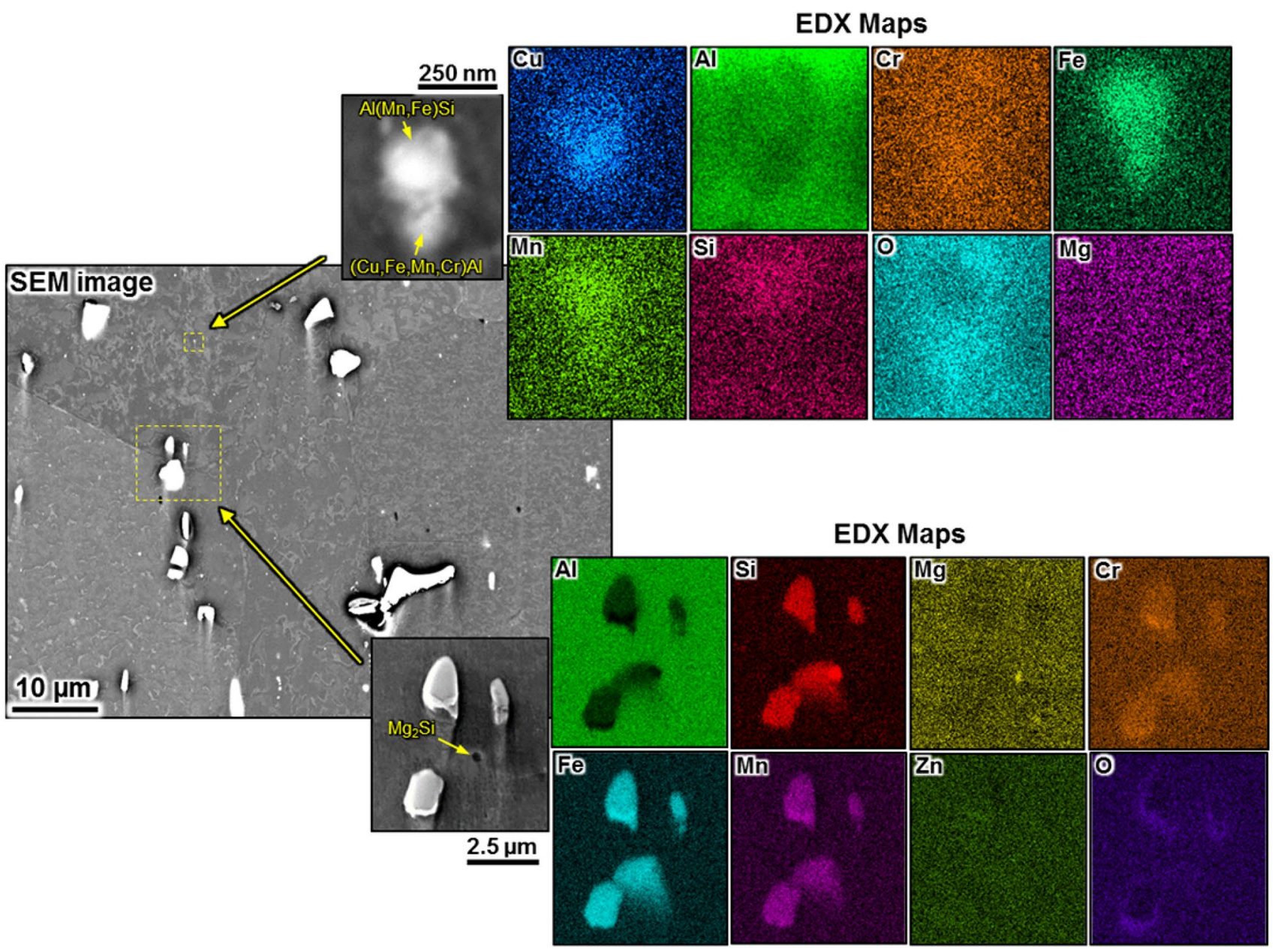

Fig. 4 Numerous inter- and transgranular IMP's embedded in the microstructure shown in the SEM image (left) with corresponding EDX maps of an aluminum-manganese silicide and a copper aluminide (top) and of a magnesium silicide (bottom)

due to a lower mean atomic number than the matrix. All IMP's except for $\mathrm{Al}_{2} \mathrm{Cu}$ contain $\mathrm{Si}, \mathrm{Fe}, \mathrm{Mn}$, and $\mathrm{Cr}$, (Fig. 4).

\subsection{Volta Potential Measurements}

The local Volta potentials (vs. Pt) measured over a region containing $\mathrm{Al}_{2} \mathrm{Cu}$ in dry air $(27 \% \mathrm{RH})$ are shown in Fig. 5a-d. The $\mathrm{Al}_{2} \mathrm{Cu}$ has a spherical shape with ca. $250 \mathrm{~nm}$ in diameter and is seen to protrude the surface by $\approx 25 \mathrm{~nm}$, indicating higher hardness than the matrix (Fig. 5a). In general, the exposure conditions exhibit a strong influence of the measured potentials. The measured Volta potentials over the $\mathrm{Al}_{2} \mathrm{Cu}$ show lower values than that over the matrix in ambient air $(27 \% \mathrm{RH})$, indicating anodic character of the $\mathrm{Al}_{2} \mathrm{Cu}$ in reference to the matrix. The increase of RH decreases the Volta potential difference between the matrix and the $\mathrm{Al}_{2} \mathrm{Cu}$. The matrix seems to be more influenced than the $\mathrm{Al}_{2} \mathrm{Cu}$ in humid environment. Figure 6 summarizes the change of the Volta potential difference measured between the $\mathrm{Al}_{2} \mathrm{Cu}$ and the neighboring aluminum matrix as a function of RH. Apparently, the anodic character of $\mathrm{Al}_{2} \mathrm{Cu}$ relative to the neighboring aluminum matrix remains in humid air, but decreases with the increase of $\mathrm{RH}$.

Next, the Volta potential change of an $\mathrm{Mg}_{2} \mathrm{Si}$ was analyzed (Fig. 5e-h). In ambient air, the $\mathrm{Mg}_{2} \mathrm{Si}$ exhibits lower Volta potentials than the matrix, indicating an anodic character. The average Volta potential difference between the $\mathrm{Mg}_{2} \mathrm{Si}$ and the matrix is $20 \mathrm{mV}$. Furthermore, an increase of RH decreases the electrochemical nobility of both phases, with the matrix apparently more than the silicide. The nobility of the silicide is seen to flip over from anodic to cathodic at $81 \%$ RH. Figure 6 summarizes the mean Volta potential difference of $\mathrm{Mg}_{2} \mathrm{Si}$ and the neighboring matrix. The silicide is seen to remain cathodic with respect to the neighboring matrix at elevated RH. 

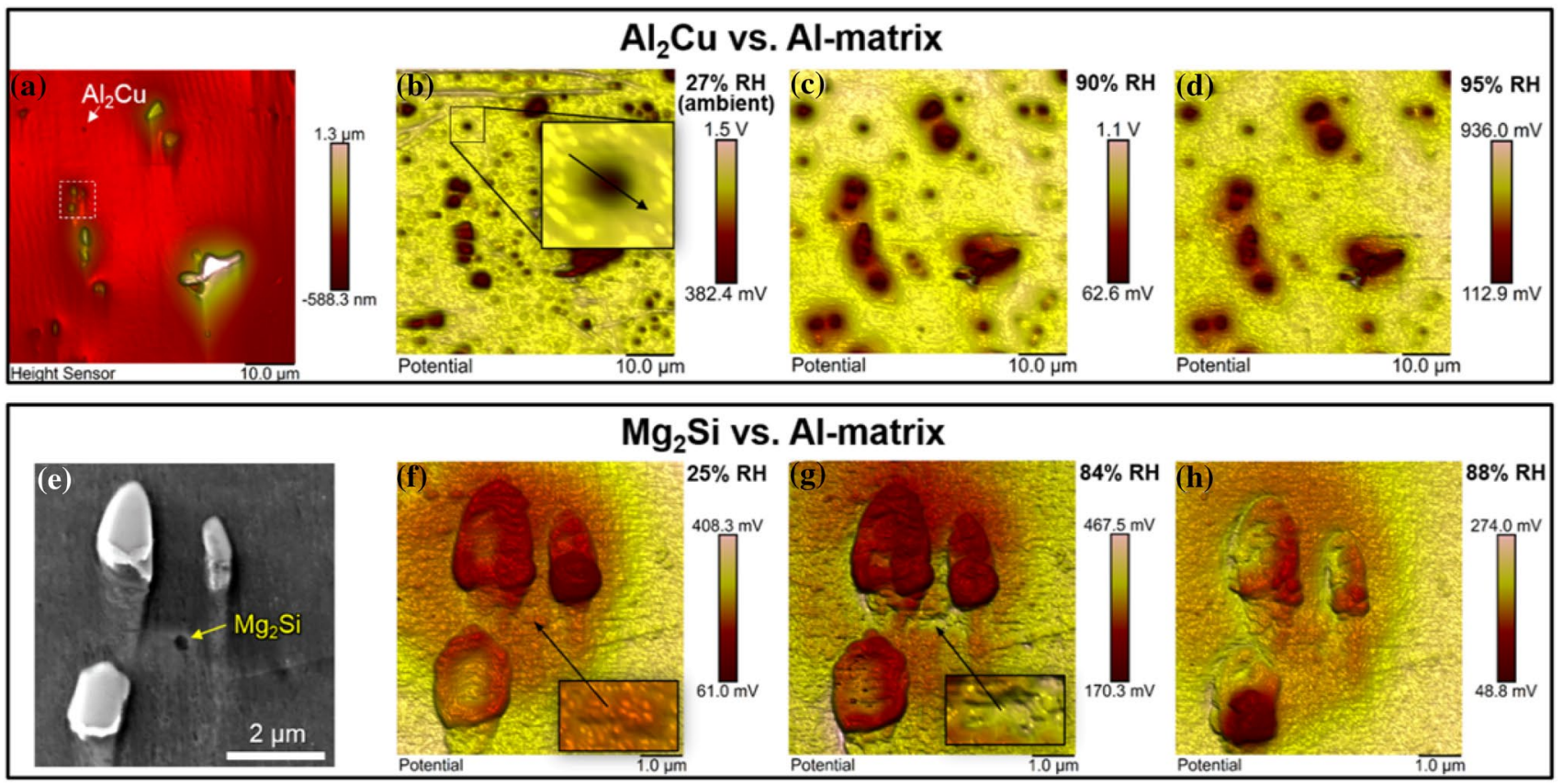

Fig. 5 Volta potential measurements of $\mathrm{Al}_{2} \mathrm{Cu}$ and $\mathrm{Mg}_{2} \mathrm{Si}$ in the area shown in Fig. 4(left) as a function of RH in reference to their neighboring aluminum matrix: a Topography map, b corresponding Volta Potential differences map obtained in ambient air $(27 \% \mathrm{RH})$ of the same region shown in a, $\mathbf{c}$ at $90 \% \mathrm{RH}$, and $\mathbf{d}$ at $95 \% \mathrm{RH}$ of a region containing $\mathrm{Al}_{2} \mathrm{Cu}$ (measurement area was $60 \mu \mathrm{m} \times 60 \mu \mathrm{m}$ ); e BSE-

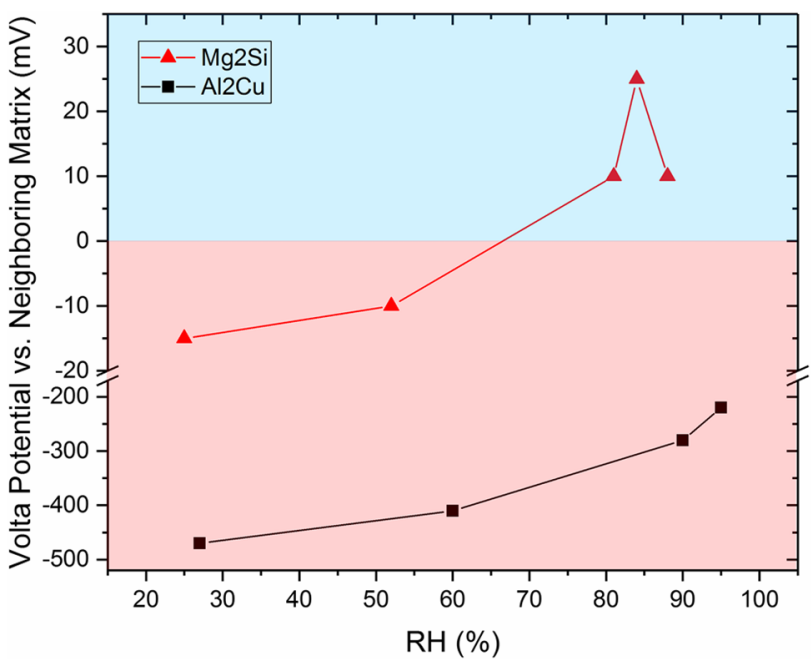

Fig. 6 Measured Volta potential difference (in average) between IMP's $\left(\mathrm{Mg}_{2} \mathrm{Si}\right.$ and $\left.\mathrm{Al}_{2} \mathrm{Cu}\right)$ and their neighboring Al-matrix as a function of RH. Negative values imply anodic character (red background) and positive values imply cathodic character (blue background) of the IMP relative to their neighboring Al-matrix
SEM micrograph showing a $\mathrm{Mg}_{2} \mathrm{Si}$ intermetallic, b corresponding topography map of the same region shown in a, corresponding Volta potential differences maps obtained at f $25 \% \mathrm{RH}, \mathbf{g} 84 \% \mathrm{RH}, \mathbf{h} 88 \%$ $\mathrm{RH}$ (measurement area was $7 \mu \mathrm{m} \times 7 \mu \mathrm{m}$ ). All potentials are in reference to $\mathrm{Pt}$

\section{Discussion}

The DFT calculations provide theoretical explanations of the influence of adhering $\mathrm{ML}$ of $\mathrm{H}_{2} \mathrm{O}$ on the work function and Volta potential of aluminum as well as of $\mathrm{Mg}_{2} \mathrm{Si}$ and $\mathrm{Al}_{2} \mathrm{Cu}$. The calculations suggest that water adlayers largely influence the nobilities of all microstructure constituents. Water adsorbed on the surface reduces the Volta potential differences between the IMP's and Al, which can lead to nobility inversions of the IMP's in reference to $\mathrm{Al}(111)$ when the surface is fully covered with water.

The orientation of the molecule dipole is a key factor that influences the work function of metals when exposed to molecular adsorption [53]. The calculations have shown that the work function of each surface decreases when water adsorbs on the surface (Table 1), which indicates that the net orientation of water molecules is pointing upwards [54, 55]. The optimized configuration of $1 \mathrm{ML}$ of water on $\mathrm{Al}(111)$ has two $\mathrm{H}_{2} \mathrm{O}$ molecules laying upright and two laying downwards. The work function of all atomic terminals of $\mathrm{Mg}_{2} \mathrm{Si}$ decreases with increasing water coverage, converging to values between 2.6 and $2.7 \mathrm{eV}$ (Table 1). 
Bare surface

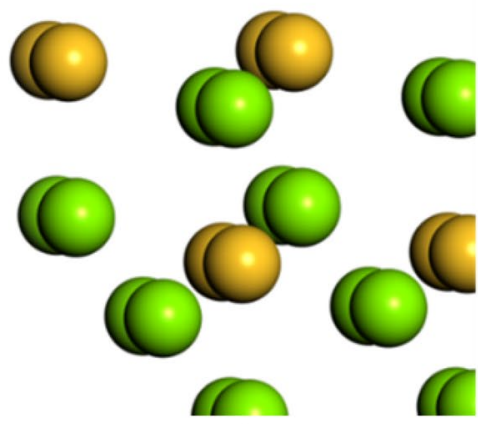

(a)
Surface with $\mathrm{H}_{2} \mathrm{O}$

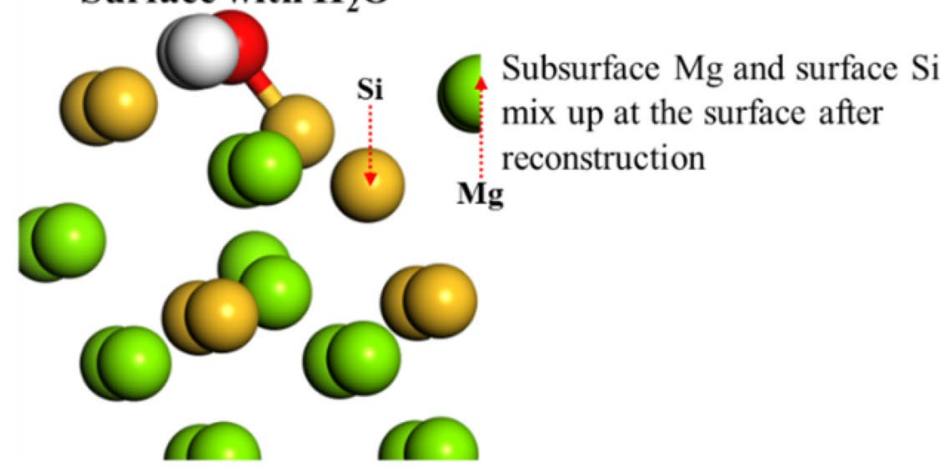

(b)
Fig. 7 Side view of an optimized atomic structure of $\mathrm{Mg}_{2} \mathrm{Si}(111)-\mathrm{Si}$ terminal (a), and rearranged surface atoms with one adsorbed $\mathrm{H}_{2} \mathrm{O}$ molecule (b). $\mathrm{Si}$ and $\mathrm{Mg}$ atoms are shown in yellow and green colors,

The configuration of adsorbed $\mathrm{H}_{2} \mathrm{O}$ on $\mathrm{Mg}_{2} \mathrm{Si}(111)-\mathrm{Si}$ surface suggests that the initial adsorption of $\mathrm{H}_{2} \mathrm{O}$ leads to a rearrangement of the surface atoms (Fig. 7). Interaction of the first adhering $\mathrm{H}_{2} \mathrm{O}$ molecules with the metal atoms results in a displacement of bulk $\mathrm{Mg}$ atoms towards the outermost surface, whereas $\mathrm{Si}$ atoms are shifted slightly towards the bulk interior. Consequently, this leads to a compositional change (relaxation) of the outermost surface of the $\mathrm{Mg}_{2} \mathrm{Si}(111)$-Si terminal, showing a mixed structure of $\mathrm{Mg}$ and $\mathrm{Si}$ atoms. This may be the reason for the same work functions (2.6 and $2.7 \mathrm{eV}$ ) at a water coverage of $2 \mathrm{ML}$.

Bare $\mathrm{Mg}_{2} \mathrm{Si}(111)-\mathrm{Si}, \quad \mathrm{Al}_{2} \mathrm{Cu}(110)-\mathrm{Al} 2$, and $\mathrm{Al}_{2} \mathrm{Cu}(110)-\mathrm{Cu}$ were initially cathodic with respect to $\mathrm{Al}(111)$, but they became anodic upon $\mathrm{H}_{2} \mathrm{O}$ adsorption at $1 \mathrm{ML}$. In contrast, $\mathrm{Mg}_{2} \mathrm{Si}(111)-\mathrm{Mg}$ and $\mathrm{Mg}_{2} \mathrm{Si}(110)-\mathrm{MgSi}$ remained anodic relative to $\mathrm{Al}(111)$ with increasing $\mathrm{H}_{2} \mathrm{O}$ coverage. The nobility inversion from cathodic to anodic relative to $\mathrm{Al}(111)$ for $\mathrm{Mg}_{2} \mathrm{Si}(111)-\mathrm{Si}, \mathrm{Al}_{2} \mathrm{Cu}(110)-\mathrm{Al}_{2}$, and $\mathrm{Al}_{2} \mathrm{Cu}(110)-\mathrm{Cu}$ upon water adsorption is most-likely related to the rearrangement of surface atoms (relaxation), causing a compositional variation of the outermost surface due to the interaction of water molecules with the metal atoms (Figs. 7, 8). This explanation may also be applied to all other phases irrespective of their atomic terminal.

The optimized structures of $\mathrm{Al}_{2} \mathrm{Cu}(110)-\mathrm{Al}_{2}$ and $\mathrm{Al}_{2} \mathrm{Cu}(110)-\mathrm{Cu}$ with $1 \mathrm{ML}$ of $\mathrm{H}_{2} \mathrm{O}$ (Fig. 8) suggest that adhering water molecules may have caused some relaxation of the outermost surface atoms. The d-spacing of the surface atoms showed a contraction of 0.1 and $0.05 \AA$ for $\mathrm{Al}_{2} \mathrm{Cu}(110)-\mathrm{Al} 2$ and $\mathrm{Al}_{2} \mathrm{Cu}(110)-\mathrm{Cu}$ terminals, respectively, when water was adsorbed. Thus, adsorbed water on the surface can alter the structure of the outermost surface of the metals investigated, and may lead to nobility changes. This provides an alternative explanation for the different polarities for various IMP's reported in aluminum and magnesium respectively. The arrows indicate that the $\mathrm{Mg}$ atom is pulled towards the surface whereas the $\mathrm{Si}$ atom is repulsed towards the bulk interior

alloys [56] in addition to de-alloying and oxide formation/ dissolution, often proposed in the literature.

It should be borne in mind that DFT has limitations when modeling water-covered systems. The temperature in DFT calculation is $0 \mathrm{~K}$ and, therefore, all the considered structures are statically frozen. The considered metal and IMP's are simple systems with well-defined structures. Moreover, up to $2 \mathrm{ML}$ of water were considered in the calculations only due to limitations in the model and computational tools. In reality, commercial alloys are usually polycrystalline materials and, therefore, crystallographic orientations as well as surface defects can complicate the calculations. Furthermore, the amount of adsorbed water can be far more than $2 \mathrm{ML}$ in ambient environment, in particular at high RH. Thick water adlayers may further alter the Volta potentials and, hence, affect the electrochemical nobilities of the aluminum alloy microstructure. The surface of the sample used for SKPFM experiments was much more complex than that considered for the DFT calculations. The alloy was always in contact with the ambient environment and, therefore, was continuously exposed to gas molecules in air, which certainly led to the formation of oxides/hydroxides on the surface and, perhaps, also to early stages of atmospheric corrosion. All these aspects could not be taken into consideration in the DFT calculations, and therefore, a direct one-by-one comparison of DFT with SKPFM data is not possible. However, both DFT and SKPFM showed good agreement in the change of Volta potential as a function of water-exposed environment.

Both the DFT calculations and SKPFM measurements indicate that there are large Volta potential differences between the IMP's and the aluminum matrix. The magnitude of the Volta potential difference between dissimilar microstructural constituents is a quantitative measure for microgalvanic corrosion $[35,36,47,49,50,52,57-62]$. Therefore, 


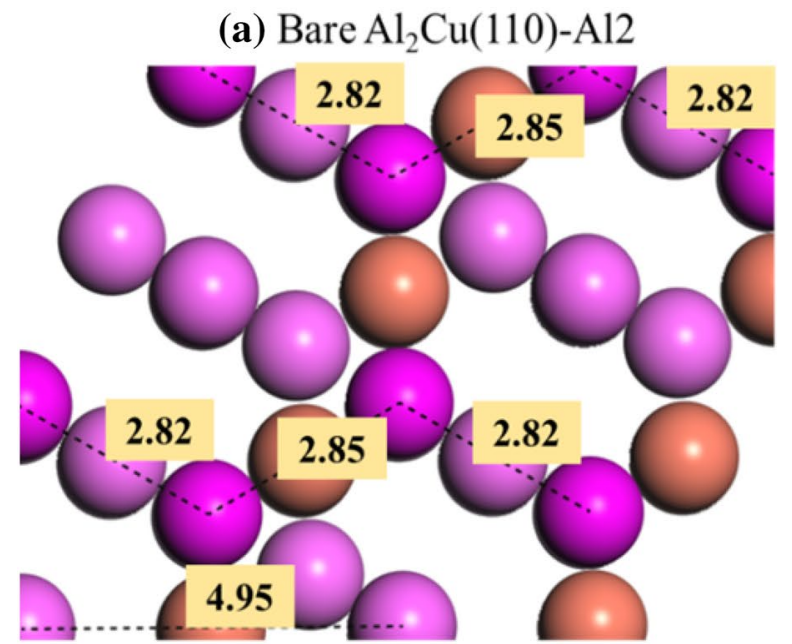

(c) $\operatorname{Bare} \mathrm{Al}_{2} \mathrm{Cu}(110)-\mathrm{Cu}$

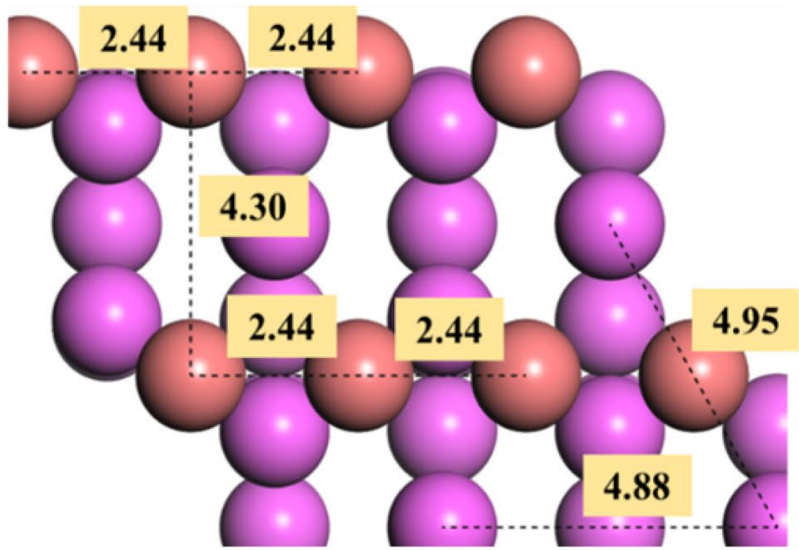

Fig. 8 Top view of optimized atomic structures of bare $\mathrm{Al}_{2} \mathrm{Cu}(110)-\mathrm{Al} 2$ terminal (a) and $\mathrm{Al}_{2} \mathrm{Cu}(110)-\mathrm{Cu}$ terminal (c), and corresponding surface configurations with $1 \mathrm{ML}$ of $\mathrm{H}_{2} \mathrm{O}$ on $\mathrm{Al}_{2} \mathrm{Cu}(110)-\mathrm{Al} 2$ (b) and $\mathrm{Al}_{2} \mathrm{Cu}(110)-\mathrm{Cu}(\mathbf{d}) . \mathrm{Al}$ atoms are in purple,

a driving force for localized attack can be expected which indeed is commonly observed in aluminum and magnesium alloys [34, 63-66].

The Volta potential measurements show that $\mathrm{Al}_{2} \mathrm{Cu}$ in the aged sample is anodic relative to the alloy matrix and remains anodic during exposure to humidified air. $\mathrm{Mg}_{2} \mathrm{Si}$ was also anodic with respect to the matrix but became cathodic when the humidity reached $\geq 81 \% \mathrm{RH}$. Its polarity remained cathodic when the RH was set back to ambient air, clearly indicating a modified surface caused by water adsorption or corrosion. Introduction of water, obviously, affects the electrochemical nobility of all phases. The DFT calculations suggest that different surface terminals of IMP's may exhibit different polarity, and relaxation and/or reconstruction of water-covered surfaces could be further reasons

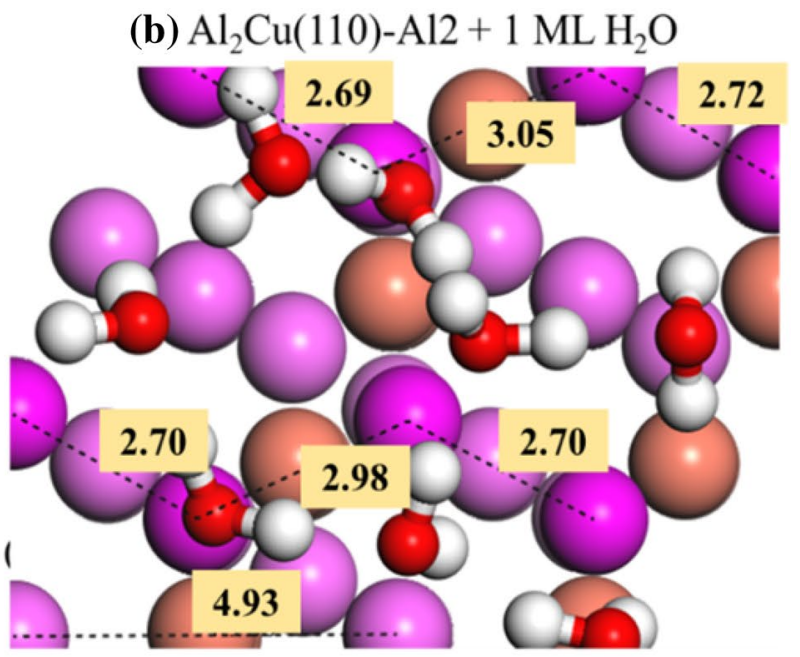

(d) $\mathrm{Al}_{2} \mathrm{Cu}(110)-\mathrm{Cu}+1 \mathrm{ML} \mathrm{H}_{2} \mathrm{O}$

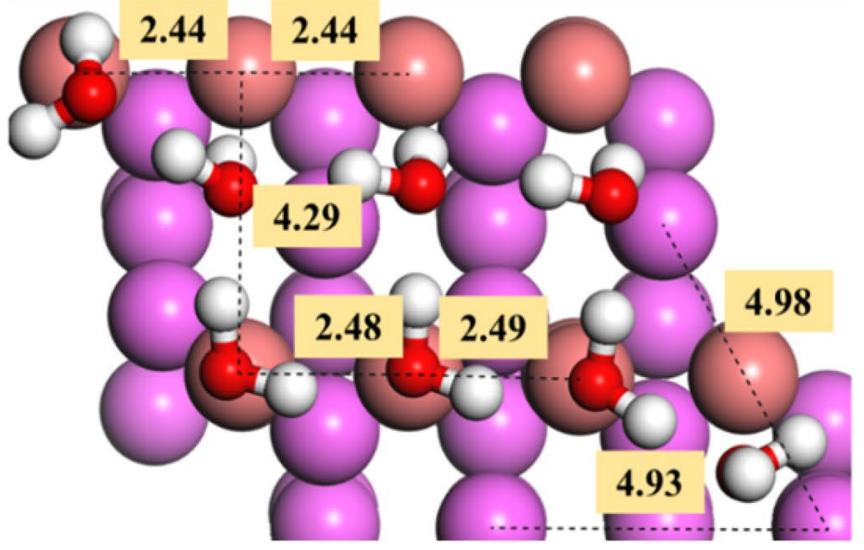

$\mathrm{Cu}$ in orange, $\mathrm{H}$ in white, and $\mathrm{O}$ in red colors. The d-spacings $(\AA)$ are highlighted in brackets and show inter-atomic distances along the dashed lines

for nobility inversions, which is predicted by the calculations and observed by the measurements.

Oxide formation, oxide dissolution, and de-alloying phenomena can also change the Volta potential of a phase. In dry atmosphere, the surface of metals is usually covered by a dense and protective (passive) metal-oxide layer which impedes corrosion reactions [67-69]. It has been reported that the surface of $\mathrm{Mg}_{2} \mathrm{Si}$ can form a passive oxide layer [70-72], which grows with time and results in an enhanced electrochemical nobility in both ambient air and corrosive environments [71]. The investigated sample was exposed to laboratory air for 2 months, allowing the formation of oxide/hydroxide on the surface (aging). The Volta potential measured by SKPFM is a weighted average of the Volta potentials from all surface constituents, with 
a depth resolution of a few ̊ngstroms to a few nanometers [73]. Hence, the contribution to the Volta potential of the surface oxide/hydroxide and other adhering species is predominant, and could have altered the electrochemical nobility of both the IMP's and the aluminum matrix.

Volta potential differences of ca. $300 \mathrm{mV}$ between $\mathrm{Mg}_{2} \mathrm{Si}$ and the aluminum matrix have been reported [74]. However, in this work, small differences of maximum $25 \mathrm{mV}$ were measured between the $\mathrm{Mg}_{2} \mathrm{Si}$ and the alloy matrix, and the $\mathrm{Mg}_{2} \mathrm{Si}$ was anodic in reference to the matrix. The calculation show that the IMP's are cathodic with respect to aluminum when no water is present. The experimental results show, however, anodic properties of both IMP's with respect to the alloy matrix. The oxide/ hydroxide formed on the surface during laboratory air exposure is most likely the reason for the apparent discrepancy. SKPFM was performed at $25-27 \% \mathrm{RH}$, and, therefore, one ML of water may have been further adhering on the surface. DFT calculations in dry conditions (no water) are, therefore, not directly comparable with measured data in lab ambient conditions.

The DFT calculations show that all IMP's exhibit anodic character with respect to the oxide-covered matrix with and without adsorbed water (Fig. 3b), which is in good agreement with the measurement results. The $\alpha-\mathrm{Al}_{2} \mathrm{O}_{3}$ may not be entirely comparable with the naturally-grown oxide on the commercial alloy but certainly reflects the nature of oxidized aluminum and the change of its Volta potential. Therefore, the calculations with $\alpha-\mathrm{Al}_{2} \mathrm{O}_{3}$ show comparable Volta potential differences (in the qualitative sense) between the IMP's and the aluminum matrix with SKPFM data measured on the commercial alloy. Hence, the nobility inversion seen in both calculation and measurements can be explained by the formation of a surface oxide, which led to an increase of the work function of aluminum. Likewise, the formation of oxide/hydroxide on IMP's can also enhance their nobility, which could further explain the enhanced nobility of the $\mathrm{Mg}_{2} \mathrm{Si}$ compared to that reported elsewhere [40, 74, 75].

The introduction of humid air led to water adsorption on the surface of the alloy, which resulted in reconstruction and relaxation of outermost surface atoms (Figs. 7, 8). Water adsorption may have caused further surface reactions, such as passivation or de-alloying, which is known to modify the surface nature of metals. Passivation can increase the nobility of a metal and protect the metal from dissolution. On the other hand, $\mathrm{Mg}_{2} \mathrm{Si}$ in aluminum alloys has been shown to de-alloy in $\mathrm{Mg}$ in neutral solutions and to become enriched in $\mathrm{Si}$, resulting in an increase of electrochemical nobility [70]. This might further explain the observed polarity inversion from anodic to cathodic. $\mathrm{Mg}$ is the most active element in alloy AA6063 and plays a vital role in the nobility of $\mathrm{Mg}_{2} \mathrm{Si}$. The thickness of water adlayer is more than $2 \mathrm{ML}$ at high $\mathrm{RH}$, and it is therefore likely that de-alloying of $\mathrm{Mg}$ in $\mathrm{Mg}_{2} \mathrm{Si}$ occurred during the exposure to humid air, which can explain the observed nobility inversion from anodic to cathodic with respect to the neighboring matrix. DFT calculations did not consider de-alloying phenomena at elevated levels of water coverage. Post-exposure surface examination by both AFM and SEM showed that the sample surface changed its appearance, manifested by newly-formed oxidation products on large IMP's in the vicinity of the $\mathrm{Mg}_{2} \mathrm{Si}$ (not shown here). The $\mathrm{Mg}_{2} \mathrm{Si}$ was not protruding the surface anymore and became slightly recessed indicating that localized corrosion (de-alloying) had indeed occurred during the exposure to humid air.

Most of the IMP's, including $\mathrm{Al}_{2} \mathrm{Cu}$, in the microstructure usually show cathodic character with respect to the matrix when the material is freshly-polished, which is typically reported in the literature. Natural oxidation, however, as shown in this paper can lead to nobility inversions within the microstructure so that the IMP's, including the aluminide, become anodic with respect to the aluminum matrix. Similar observations were reported by Leblanc et al. who monitored a polarity change of the measured Volta potential over an $\mathrm{Al}_{2} \mathrm{CuMg}$ IMP when the surface was sputteretched (oxides removed) [76]. Zhou et al. [63] reported dealloying of $\mathrm{Al}$ from $\mathrm{Al}_{2} \mathrm{Cu}$ with enrichment of $\mathrm{Cu}$ on the outermost surface, in-line with other works [77]. Frankel et al. showed that the oxide formed on IMP's could alter their electrochemical nobility upon exposure to chloridecontaining aqueous solutions, leading to polarity inversions of local Volta potentials [76]. In this study, de-alloying of $\mathrm{Al}$ in $\mathrm{Al}_{2} \mathrm{Cu}$ may have been possible but it is not expected to occur to a large extent. The trend of the change of the measured Volta potential differences between the $\mathrm{Al}_{2} \mathrm{Cu}$ and the matrix as a function of $\mathrm{RH}$ is in good agreement with the DFT calculations. DFT calculations showed that $\mathrm{Al}_{2} \mathrm{Cu}$ can be either anodic or cathodic with respect to $\mathrm{Al}(111)$ depending on the surface terminal and the level of $\mathrm{H}_{2} \mathrm{O}$ coverage. $\mathrm{Al}_{2} \mathrm{Cu}(110)-\mathrm{Cu}$ can be cathodic at water coverages of $2 \mathrm{ML}$, whereas $\mathrm{Al}_{2} \mathrm{Cu}(110)-\mathrm{Al} 2$ can be anodic with respect to $\mathrm{Al}(111)$, and therefore, it is possible that the $\mathrm{Al}_{2} \mathrm{Cu}$ had an Al2 terminal.

In summary, DFT Volta potential calculations have provided valuable information about local electrochemical nobilities of a multi-phase aluminum alloy microstructure. SKPFM measurements yielded useful information for the assessment of the tendency for micro-galvanic corrosion induced by microstructure heterogeneities, as reported extensively in the literature. The nature of the IMP's with varying surface terminal, humidity, and local surface reactions, such as de-alloying and oxide growth or dissolution, can obviously alter the nobility of a phase and even lead to nobility inversions within the microstructure. The Volta potential gives only an indication for the corrosion propensity of a certain phase in the microstructure. What is anodic 
in one electrolyte could be cathodic in another and, therefore, one should be careful in the interpretation of Volta potential data (there is further a time-dependent nobility change possible during exposure). As demonstrated in this study, the combination of DFT and SKPFM can provide complementary information that is important for a better understanding of localized corrosion of aluminum alloys and may be used to predict the tendency for localized corrosion, in particular in applications akin to atmospheric exposures.

\section{Conclusions}

First-principle DFT calculations of work functions and Volta potentials have been performed for $\mathrm{Al}(111)$ and $\mathrm{Mg}_{2} \mathrm{Si}$ and $\mathrm{Al}_{2} \mathrm{Cu}$ with different atomic surface terminals as a function of adsorbed water. The calculation results have been compared with local Volta potential data measured by SKPFM on a commercial Al alloy AA6063-T5. The following conclusions can be drawn:

1. DFT calculations are in good agreement with SKPFM data for comparable conditions, both showing similar trends in changes of Volta potential differences between microstructural constituents as a function of adhering water.

2. Surface terminals can largely affect the electrochemical nobility of $\mathrm{Mg}_{2} \mathrm{Si}$ and $\mathrm{Al}_{2} \mathrm{Cu}$, and, depending on the terminal, these can be either anodic or cathodic with respect to the aluminum matrix.

3. According to the calculations, water adsorption causes a reduction of the Volta potential difference between microstructural constituents, which can further lead to an inversion of their relative electrochemical nobilities at higher magnitudes of water coverage $\left(\geq 1 \mathrm{ML}\right.$ of $\left.\mathrm{H}_{2} \mathrm{O}\right)$.

4. SKPFM measurements show anodic character of $\mathrm{Al}_{2} \mathrm{Cu}$ and $\mathrm{Mg}_{2} \mathrm{Si}$ relative to the matrix in ambient air. $\mathrm{Al}_{2} \mathrm{Cu}$ remains anodic at all humidities while $\mathrm{Mg}_{2} \mathrm{Si}$ becomes cathodic upon exposure to $\geq 81 \% \mathrm{RH}$, with the latter due to de-alloying and oxide dissolution.

5. The surface oxide has a large influence on the Volta potential and can lead to nobility inversions within the microstructure.

Acknowledgements First of all, we sincerely wish to thank Prof Gabor Somorjai for his long-lasting support of surface science related activities at KTH Royal Institute of Technology. Furthermore, a scholarship from the Chinese Scholarship Council to Min Liu is greatly acknowledged. We are grateful to the Swedish National Infrastructure for Computing (SNIC) for the use of Swedish supercomputing resource in the DFT calculations. We acknowledge the partial support by Swedish Foundation for Strategic Research (SSF project RMA11-0090), and also thank the support from the 111 Project (Grant No. B12012) in China for promoting the international collaboration.

Open Access This article is distributed under the terms of the Creative Commons Attribution 4.0 International License (http://creativeco mmons.org/licenses/by/4.0/), which permits unrestricted use, distribution, and reproduction in any medium, provided you give appropriate credit to the original author(s) and the source, provide a link to the Creative Commons license, and indicate if changes were made.

\section{References}

1. Zhang X, Sewell TE, Glatz B, Sarupria S, Getman RB (2017) On the water structure at hydrophobic interfaces and the roles of water on transition-metal catalyzed reactions: a short review. Catal Today 285:57-64. https://doi.org/10.1016/j.cattod.2017.02.002

2. Liu X, Maegawa Y, Goto Y, Hara K, Inagaki S (2016) Heterogeneous catalysis for water oxidation by an iridium complex immobilized on bipyridine-periodic mesoporous organosilica. Angew Chem Int Ed 55(28):7943-7947. https://doi.org/10.1002/ anie. 201601453

3. Qasim D, Vlasak L, Pital A, Beckman T, Mutanda N, AbbottLyon $H$ (2017) Adsorption of water, methanol, and formic acid on $\mathrm{Fe}_{2} \mathrm{NiP}$, a meteoritic mineral analogue. J Phys Chem $\mathrm{C}$ 121(25):13645-13654. https://doi.org/10.1021/acs.jpcc.7b01312

4. Pruppacher HR, Klett JD (1999) Microphysics of clouds and precipitation. J Atmos Chem 32(3):420-422. https://doi. org/10.1023/a:1006136611623

5. Glatstein DA, Francisca FM (2015) Influence of pH and ionic strength on $\mathrm{Cd}, \mathrm{Cu}$ and $\mathrm{Pb}$ removal from water by adsorption in Na-bentonite. Appl Clay Sci 118:61-67. https://doi.org/10.1016/j. clay.2015.09.003

6. Tiping D, Jianfei GAO, Shihong T, Huaibai W, Ming LI, Chengyu W, Xurong LUO, Dan H (2016) Chemical and isotopic characters of the water and suspended particulate materials in the yellow river and their geological and environmental implications. Acta Geol Sin 90(1):285-351. https://doi. org/10.1111/1755-6724.12658

7. Yu J, Tahmasebi A, Han Y, Yin F, Li X (2013) A review on water in low rank coals: the existence, interaction with coal structure and effects on coal utilization. Fuel Process Technol 106:9-20. https://doi.org/10.1016/j.fuproc.2012.09.051

8. Huang H, Schwab K, Jacangelo JG (2009) Pretreatment for low pressure membranes in water treatment: a review. Environ Sci Technol 43(9):3011-3019. https://doi.org/10.1021/es802473r

9. Ding C, Qin W, Wang N, Liu G, Wang Z, Yan P, Shi J, Li C (2014) Solar-to-hydrogen efficiency exceeding 2.5\% achieved for overall water splitting with an all earth-abundant dual-photoelectrode. Phys Chem Chem Phys 16(29):15608-15614. https://doi. org/10.1039/C4CP02391A

10. Zhang K, Guo L (2013) Metal sulphide semiconductors for photocatalytic hydrogen production. Catal Sci Technol 3(7):1672-1690. https://doi.org/10.1039/C3CY00018D

11. C L, GA MH S (1982) Mg-and Si-doped iron oxides for the photocatalyzed production of hydrogen from water by visible light ( $2.2 \mathrm{eV}$ less than or equal to $\mathrm{h}$ nu less than or equal to $2.7 \mathrm{eV}$ ). $\mathrm{J}$ Catal 78(2):341-351

12. Rivera-Utrilla J, Sánchez-Polo M, Ferro-García M, PradosJoya G, Ocampo-Pérez R (2013) Pharmaceuticals as emerging contaminants and their removal from water: a review. Chemosphere 93(7):1268-1287. https://doi.org/10.1016/j.chemospher e.2013.07.059 
13. Rubasinghege G, Grassian VH (2013) Role(s) of adsorbed water in the surface chemistry of environmental interfaces. Chem Commun 49(30):3071-3094. https://doi.org/10.1039/C3CC38872G

14. Rossmeisl J, Nørskov JK, Taylor CD, Janik MJ, Neurock M (2006) Calculated phase diagrams for the electrochemical oxidation and reduction of water over Pt(111). J Phys Chem B 110(43):2183321839. https://doi.org/10.1021/jp0631735

15. Bajdich M, García-Mota M, Vojvodic A, Nørskov JK, Bell AT (2013) Theoretical investigation of the activity of cobalt oxides for the electrochemical oxidation of water. J Am Chem Soc 135(36):13521-13530. https://doi.org/10.1021/ja405997s

16. Xu L, Bluhm H, Salmeron M (1998) An AFM study of the tribological properties of $\mathrm{NaCl}(100)$ surfaces under moist air. Surf Sci 407(1):251-255. https://doi.org/10.1016/S0039-6028(98)00199-X

17. Furlong O, Li Z, Gao F, Tysoe WT (2008) Surface and tribological chemistry of water and carbon dioxide on copper surfaces. Tribol Lett 31(3):167-176. https://doi.org/10.1007/s11249-008-9349-7

18. Stratmann M, Streckel H (1990) On the atmospheric corrosion of metals which are covered with thin electrolyte layers-I. Verification of the experimental technique. Corros Sci 30(6):681-696. https://doi.org/10.1016/0010-938X(90)90032-Z

19. Stratmann M, Streckel H (1990) On the atmospheric corrosion of metals which are covered with thin electrolyte layers-II. Experimental results. Corros Sci 30(6):697-714. https://doi. org/10.1016/0010-938X(90)90033-2

20. Thiel PA, Madey TE (1987) The interaction of water with solid surfaces: fundamental aspects. Surf Sci Rep 7(6):211-385. https ://doi.org/10.1016/0167-5729(87)90001-X

21. Henderson MA (2002) The interaction of water with solid surfaces: fundamental aspects revisited. Surf Sci Rep 46(1):1-308. https://doi.org/10.1016/S0167-5729(01)00020-6

22. Hodgson A, Haq S (2009) Water adsorption and the wetting of metal surfaces. Surf Sci Rep 64(9):381-451. https://doi. org/10.1016/j.surfrep.2009.07.001

23. Leygraf C, Wallinder IO, Tidblad J, Graedel T (2016) Atmospheric corrosion, 2nd edn. Wiley, Hoboken

24. Schindelholz E, Kelly RG (2012) Wetting phenomena and time of wetness in atmospheric corrosion: a review. Corros Rev. https ://doi.org/10.1515/corrrev-2012-0015

25. Phipps PBP, Rice DW (1979) The role of water in atmospheric corrosion. In: Corrosion chemistry, vol 89. ACS symposium series. American Chemical Society, pp 235-261. https://doi. org/10.1021/bk-1979-0089.ch008

26. Forslund M, Leygraf C (1996) A quartz crystal microbalance probe developed for outdoor in situ atmospheric corrosivity monitoring. J Electrochem Soc 143(3):839-844. https://doi. org/10.1149/1.1836546

27. Lee S, Staehle RW (1997) Adsorption of water on copper, nickel, and iron. CORROSION 53(1):33-42. https://doi. org/10.5006/1.3280431

28. Persson D, Leygraf C (1995) Initial interaction of sulfur dioxide with water covered metal surfaces: an in situ IRAS study. J Electrochem Soc 142(5):1459-1468. https://doi.org/10.1149/1.20485 97

29. Aastrup T, Leygraf C (1997) Simultaneous infrared reflection absorption spectroscopy and quartz crystal microbalance measurements for in situ studies of the metal/atmosphere interface. J Electrochem Soc 144(9):2986-2990. https://doi.org/10.1149/1.18379 48

30. Johnson CM, Tyrode E, Leygraf C (2006) Atmospheric corrosion of zinc by organic constituents: I. The role of the zinc/water and water/air interfaces studied by infrared reflection/absorption spectroscopy and vibrational sum frequency spectroscopy. J Electrochem Soc 153(3):B113-B120. https://doi.org/10.1149/1.21647 88
31. Masuda H (1996) Nanoscopic analysis of aqueous corrosion by scanning tunneling microscopy. Corrosion 52(6):435-439. https ://doi.org/10.5006/1.3292131

32. Kunze J, Maurice V, Klein LH, Strehblow H-H, Marcus P (2004) In situ STM study of the duplex passive films formed on $\mathrm{Cu}(111)$ and $\mathrm{Cu}(001)$ in $0.1 \mathrm{M} \mathrm{NaOH}$. Corros Sci 46(1):245-264. https:// doi.org/10.1016/S0010-938X(03)00140-9

33. Frankel GS, Guillaumin V, Schmutz P (2001) Characterization of corrosion interfaces by the scanning Kelvin probe force microscopy technique. J Electrochem Soc 148(5):B163-B173. https:// doi.org/10.1149/1.1359199

34. Davoodi A, Pan J, Leygraf C, Norgren S (2008) The role of intermetallic particles in localized corrosion of an aluminum alloy studied by SKPFM and integrated AFM/SECM. J Electrochem Soc 155(5):C211-C218. https://doi.org/10.1149/1.2883737

35. Bettini E, Kivisäkk U, Leygraf C, Pan J (2013) Study of corrosion behavior of a $22 \% \mathrm{Cr}$ duplex stainless steel: influence of nano-sized chromium nitrides and exposure temperature. Electrochim Acta 113:280-289. https://doi.org/10.1016/j.elect acta.2013.09.056

36. Jin Y, Liu M, Zhang C, Leygraf C, Wen L, Pan J (2017) Firstprinciple calculation of Volta potential of intermetallic particles in aluminum alloys and practical implications. J Electrochem Soc 164(9):C465-C473. https://doi.org/10.1149/2.0191709jes

37. Ranea VA, Schneider WF, Carmichael I (2008) DFT characterization of coverage dependent molecular water adsorption modes on $\alpha-\mathrm{Al}_{2} \mathrm{O}_{3}(0001)$. Surf Sci 602(1):268-275. https://doi. org/10.1016/j.susc.2007.10.029

38. Perdew JP, Chevary JA, Vosko SH, Jackson KA, Pederson MR, Singh DJ, Fiolhais C (1992) Atoms, molecules, solids, and surfaces: applications of the generalized gradient approximation for exchange and correlation. Phys Rev B 46(11):6671-6687. https ://doi.org/10.1103/PhysRevB.46.6671

39. Lang ND, Kohn W (1971) Theory of metal surfaces: work function. Phys Rev B 3(4):1215-1223. https://doi.org/10.1103/PhysR evB.3.1215

40. Qin Y-F, Wang S-Q (2015) Ab-initio study of the role of $\mathrm{Mg}_{2} \mathrm{Si}$ and $\mathrm{Al}_{2} \mathrm{CuMg}$ phases in electrochemical corrosion of Al alloys. J Electrochem Soc 162(9):C503-C508. https://doi. org/10.1149/2.0311509jes

41. Singh-Miller NE, Marzari N (2009) Surface energies, work functions, and surface relaxations of low-index metallic surfaces from first principles. Phys Rev B 80(23):235407

42. Moore WJ, Hummel DO, Trafara G, Holland-Moritz K (1986) Physikalische Chemie, 4. Auflage. Walter de Gruyter, New York, p 1236

43. Semov YI (1969) Work function of oxidized metal surfaces and estimation of $\mathrm{Al}_{2} \mathrm{O}_{3}$ film band structure parameters. Phys Status Solidi (B) 32(1):K41-K44 https://doi.org/10.1002/pssb.19690 320162

44. Rohwerder M, Turcu F (2007) High-resolution Kelvin probe microscopy in corrosion science: scanning Kelvin probe force microscopy (SKPFM) versus classical scanning Kelvin probe (SKP). Electrochim Acta 53(2):290-299. https://doi. org/10.1016/j.electacta.2007.03.016

45. Bockris JOM, Reddy AKN, Gamboa-Aldeco M (2002) Modern electrochemistry 2A: fundamentals of electrodics. Springer, New York

46. Bagotsky VS (2006) Fundamentals of electrochemistry. The electrochemical society series. Wiley, Hoboken

47. Anantha KH, Örnek C, Ejnermark S, Medvedeva A, Sjöström J, Pan J (2017) Correlative microstructure analysis and in situ corrosion study of AISI 420 martensitic stainless steel for plastic molding applications. J Electrochem Soc 164(4):C85-C93. https ://doi.org/10.1149/2.0531704jes 
48. Li W, Li DY (2006) Influence of surface morphology on corrosion and electronic behavior. Acta Mater 54(2):445-452. https://doi. org/10.1016/j.actamat.2005.09.017

49. Örnek C, Engelberg DL (2015) SKPFM measured Volta potential correlated with strain localisation in microstructure to understand corrosion susceptibility of cold-rolled grade 2205 duplex stainless steel. Corros Sci 99:164-171. https://doi.org/10.1016/j.corsc i.2015.06.035

50. Örnek C, Engelberg DL (2015) Correlative EBSD and SKPFM characterisation of microstructure development to assist determination of corrosion propensity in grade 2205 duplex stainless steel. J Mater Sci 51(4):1931-1948. https://doi.org/10.1007/s1085 3-015-9501-3

51. Örnek C, Engelberg DL (2016) An experimental investigation into strain and stress partitioning of duplex stainless steel using digital image correlation, X-ray diffraction and scanning Kelvin probe force microscopy. J Strain Anal Eng Des 51(3):207-219. https://doi.org/10.1177/0309324716631669

52. Örnek C, Walton J, Hashimoto T, Ladwein TL, Lyon SB, Engelberg DL (2017) Characterization of $475{ }^{\circ} \mathrm{C}$ embrittlement of duplex stainless steel microstructure via scanning Kelvin probe force microscopy and magnetic force microscopy. J Electrochem Soc 164(6):C207-C217. https://doi.org/10.1149/2.0311706jes

53. Rusu PC, Brocks G (2006) Work functions of self-assembled monolayers on metal surfaces by first-principles calculations. Phys Rev B 74(7):073414

54. Heras JM, Viscido L (1980) Work function changes upon water contamination of metal surfaces. Appl Surf Sci 4(2):238-241. https://doi.org/10.1016/0378-5963(80)90133-6

55. Tzvetkov G, Zubavichus Y, Koller G, Schmidt T, Heske C, Umbach E, Grunze M, Ramsey MG, Netzer FP (2003) Growth of $\mathrm{H}_{2} \mathrm{O}$ layers on an ultra-thin $\mathrm{Al}_{2} \mathrm{O}_{3}$ film: from monomeric species to ice. Surf Sci 543(1):131-140. https://doi.org/10.1016/S0039 $-6028(03) 01029-\mathrm{X}$

56. Iannuzzi M, Vasanth KL, Frankel GS (2017) Unusual correlation between SKPFM and corrosion of nickel aluminum bronzes. J Electrochem Soc 164(9):C488-C497. https://doi. org/10.1149/2.0391709jes

57. Sathirachinda N, Gubner R, Pan J, Kivisäkk U (2008) Characterization of phases in duplex stainless steel by magnetic force microscopy/scanning Kelvin probe force microscopy. Electrochem Solid-State Lett 11(7):C41-C45. https://doi.org/10.1149/1.29126 01

58. Sathirachinda N, Pettersson R, Pan J (2009) Depletion effects at phase boundaries in 2205 duplex stainless steel characterized with SKPFM and TEM/EDS. Corros Sci 51(8):1850-1860. https://doi. org/10.1016/j.corsci.2009.05.012

59. Sathirachinda N, Pettersson R, Wessman S, Pan J (2010) Study of nobility of chromium nitrides in isothermally aged duplex stainless steels by using SKPFM and SEM/EDS. Corros Sci 52(1):179-186. https://doi.org/10.1016/j.corsci.2009.08.057

60. Bettini E, Eriksson T, Boström M, Leygraf C, Pan J (2011) Influence of metal carbides on dissolution behavior of biomedical CoCrMo alloy: SEM, TEM and AFM studies. Electrochim Acta 56(25):9413-9419. https://doi.org/10.1016/j.elect acta.2011.08.028

61. Sathirachinda N, Pettersson R, Wessman S, Kivisäkk U, Pan J (2011) Scanning Kelvin probe force microscopy study of chromium nitrides in 2507 super duplex stainless steel-implications and limitations. Electrochim Acta 56(4):1792-1798. https://doi. org/10.1016/j.electacta.2010.08.038

62. Bettini E, Kivisäkk U, Leygraf C, Pan J (2014) Study of corrosion behavior of a 2507 super duplex stainless steel: influence of quenched-in and isothermal nitrides. Int J Electrochem Sci 9:20
63. Zhang X, Hashimoto T, Lindsay J, Zhou X (2016) Investigation of the de-alloying behaviour of $\theta$-phase $\left(\mathrm{Al}_{2} \mathrm{Cu}\right)$ in AA2024-T351 aluminium alloy. Corros Sci 108:85-93. https://doi.org/10.1016/j. corsci.2016.03.003

64. Hashimoto T, Zhang X, Zhou X, Skeldon P, Haigh SJ, Thompson GE (2016) Investigation of dealloying of $S$ phase $\left(\mathrm{Al}_{2} \mathrm{CuMg}\right)$ in AA 2024-T3 aluminium alloy using high resolution 2D and 3D electron imaging. Corros Sci 103:157-164. https://doi. org/10.1016/j.corsci.2015.11.013

65. Davoodi A, Pan J, Leygraf C, Norgren S (2008) Multianalytical and in situ studies of localized corrosion of EN AW-3003 alloy-influence of intermetallic particles. J Electrochem Soc 155(4):C138-C146. https://doi.org/10.1149/1.2834454

66. Zhang F, Nilsson J-O, Pan J (2016) In situ and operando AFM and EIS studies of anodization of $\mathrm{Al}$ 6060: influence of intermetallic particles. J Electrochem Soc 163(9):C609-C618. https://doi. org/10.1149/2.0061610jes

67. Vignal V, Delrue O, Heintz O, Peultier J (2010) Influence of the passive film properties and residual stresses on the microelectrochemical behavior of duplex stainless steels. Electrochim Acta 55(23):7118-7125. https://doi.org/10.1016/j.elect acta.2010.06.050

68. Jung R-H, Tsuchiya H, Fujimoto S (2012) XPS characterization of passive films formed on Type 304 stainless steel in humid atmosphere. Corros Sci 58(0):62-68. https://doi.org/10.1016/j.corsc i.2012.01.006

69. Sato N (2012) Basics of corrosion chemistry. In: Sharma SK (ed) Green corrosion chemistry and engineering: opportunities and challenges, 1st edn. Wiley, Weinheim

70. Linardi E, Haddad R, Lanzani L (2012) Stability analysis of the $\mathrm{Mg}_{2} \mathrm{Si}$ phase in AA 6061 aluminum alloy. Procedia Mater Sci 1:550-557. https://doi.org/10.1016/j.mspro.2012.06.074

71. Ryl J, Wysocka J, Jarzynka M, Zielinski A, Orlikowski J, Darowicki K (2014) Effect of native air-formed oxidation on the corrosion behavior of AA 7075 aluminum alloys. Corros Sci 87:150 155. https://doi.org/10.1016/j.corsci.2014.06.022

72. Li LL, Zhang B, Tian B, Zhou Y, Wang JQ, Han EH, Ke W (2017) SVET study of galvanic corrosion of $\mathrm{Al} / \mathrm{Mg}_{2} \mathrm{Si}$ couple in aqueous solutions at different pH. J Electrochem Soc 164(6):C240-C249. https://doi.org/10.1149/2.0671706jes

73. Jacobs HO, Leuchtmann P, Homan OJ, Stemmer A (1998) Resolution and contrast in Kelvin probe force microscopy. J Appl Phys 84(3):1168-1173. https://doi.org/10.1063/1.368181

74. Pech-Canul MA, Giridharagopal R, Pech-Canul MI, CoralEscobar EE (2016) Corrosion characteristics of an Al-1.78\%Si$13.29 \% \mathrm{Mg}$ alloy in chloride solutions. In: Weiland H, Rollett AD, Cassada WA (eds) ICAA13 Pittsburgh: proceedings of the 13th international conference on aluminum alloys. Springer, Cham, pp 417-423. https://doi.org/10.1007/978-3-319-48761-8_61

75. Ben-Hamu G, Eliezer D, Shin KS (2007) The role of Si and $\mathrm{Ca}$ on new wrought $\mathrm{Mg}-\mathrm{Zn}-\mathrm{Mn}$ based alloy. Mater Sci Eng A 447(1):35-43. https://doi.org/10.1016/j.msea.2006.10.059

76. Leblanc P, Frankel GS (2002) A study of corrosion and pitting initiation of AA2024-T3 using atomic force microscopy. J Electrochem Soc 149(6):B239-B247. https://doi.org/10.1149/1.14715 46

77. Buchheit RG, Grant RP, Hlava PF, Mckenzie B, Zender GL (1997) Local dissolution phenomena associated with $\mathrm{S}$ phase $\left(\mathrm{Al}_{2} \mathrm{CuMg}\right)$ particles in aluminum alloy 2024-T3. J Electrochem Soc 144(8):2621-2628. https://doi.org/10.1149/1.1837874 